\title{
DA GERICO A BETLEMME. LA MISSIONE DELLA SAPIENZA A GERICO E L'ARCHEOLOGIA ITALIANA IN PALESTINA (1997-2017) CON IL CONTRIBUTO DEL MINISTERO DEGLI AFFARI ESTERI E DELLA COOPERAZIONE INTERNAZIONALE
}

\author{
Lorenzo Nigro - Sapienza University of Rome
}

\begin{abstract}
When after the Oslo and Madrid agreements the Palestinian National Authority was established it was also provided of a Ministry of Tourism and Antiquities - Dept. of Archaeology and Cultural Heritage (MOTA-DACH). At that time, Sapienza University of Rome was chosen as ideal partner to start a new deal in the archaeology of Palestine. By contrast with an enduring colonial tradition, which foresaw a full demission of responsibility by means of the "excavation permit" given by the Host Country to the European or American digging institutions, a new project was set up at Tell esSultan, ancient Jericho, one of the most long-lived human settlement in the ancient Near East, based upon an "Agreement on cooperation", with which responsibilities and commitment to investigate, protect and rehabilitate the site were shared. The new project started in 1997 and is still continuing (13 seasons on the field have been carried out), the joint team works together as a unique team, and it has been engaged in transforming what was an almost unintelligible ruin into a prominent archaeological site, concealing the memory of some major steps of the Humankind, from the beginning of agriculture and animal breeding in the Neolithic (10,500-6000 BC), to the invention of modular architecture, the rise of the earliest city with the establishment of an urban model in the $3^{\text {rd }}$ millennium BC. No other Institution or Country can boast such a continuous and successful cooperation as Sapienza and Italy in Palestine. The Jericho joint Italian-Palestinian Expedition has produced more than 100 scientific publication, has fully rehabilitated the archaeological site providing also a correct historical interpretation of its finds, free from any pre-conceiving and political or religious distortion.

After two decades, the cooperation has become a model, and it has been expanded especially for the safeguard and protection of a heavy threatened Archaeological Heritage. With the publication of the Catalogue of the Archaeological sites of the Jericho Oasis (Rosapat 07, Rome 2011) a new step was accomplished involving the Municipality of Ariha and starting the Jericho Oasis Archaeological Park Project, which has rehabilitated and made suitable to tourist exploitation 13 main sites. In 2015 a rescue project, again founded upon an "Agreement of Cooperation" between the MOTA-DACH and Sapienza, started in Bethlehem to protect the many necropolis inside and around this city, and to reconstruct its early history. Four reports about the necropolis of Khalet al-Jama' and Jebel Daher and Bethelehem in antiquity have already been published. Moreover, a new joint research Project was also started on the site of Tell Abu Zarad, in the Province of Salfeet, which was a major city of Palestine during the Bronze and the Iron Ages, also known from ancient sources with the name of Teffah. Two seasons have already been carried out at Abu Zarad and a preliminary report was published in 2016. This last project aims at rescuing and valorizing another piece of the ancient history of the Country.
\end{abstract}

Keywords: Palestine; cooperation; archaeological heritage; MOTA-DACH; Sapienza University

Quando, a seguito degli accordi di pace israelo-palestinesi di Oslo (1993) e di Madrid (1994) fu istituita l'Autorità Nazionale Palestinese e una parte del territorio passò sotto la neonata amministrazione palestinese, venne istituito il Ministero del Turismo e delle Antichità, con un Dipartimento di Archeologia e Patrimonio Culturale (MOTA-DACH),

ISSN 0393-0300

e-ISSN 2532-5159 
incaricato di assicurare la tutela e la valorizzazione dei beni archeologici, architettonici, storici, antropologici della Palestina. Il MOTA-DACH dovette allora affrontare l'ardua sfida di impiantare un servizio di tutela del patrimonio archeologico, dotandolo degli strumenti per il controllo e la salvaguardia dei monumenti e dei giacimenti archeologici, del paesaggio, del patrimonio culturale e storico materiale e immateriale della West Bank.

In quel momento cruciale, l'Università di Roma "La Sapienza” venne chiamata, per i meriti conseguiti sul campo dalla Missione Archeologica in Siria diretta da Paolo Matthiae a Ebla, a offrire un contributo concreto di cooperazione tecnica e scientifica. Fu deciso allora di formare il personale che doveva fronteggiare una situazione resa molto complicata dall'incerto inquadramento giuridico, dalla limitata possibilità di muoversi sul territorio e da un fortissimo sviluppo urbanistico spesso incontrollato, attraverso il cantiere scuola di Tell es-Sultan, l'antica Gerico, uno dei siti archeologici più antichi e meglio conservati di tutto il Vicino Oriente ${ }^{1}$ (fig. 1). Dall'aprile del 1997 architetti, archeologi, topografi, restauratori, chimici palestinesi iniziarono a lavorare a Gerico insieme a i loro colleghi italiani, sviluppando un nuovo modello di archeologia del Vicino Oriente. Un modello di cooperazione, totalmente post-coloniale, fondato non sulla devoluzione di competenze (come tradizionalmente rappresentato dalle "concessioni di scavo"), ma su una assunzione di responsabilità congiunta, rappresentata da un "Agreement on Cooperation” che fissava gli scopi, la articolazione e i limiti rispettivi di un'attività di cooperazione mirata alla salvaguardia e alla piena valorizzazione scientifica, culturale e turistica del sito archeologico in questione ${ }^{2}$. La prospettiva dei lavori si è poi estesa alla valorizzazione con restauri, riabilitazione e formazione di personale dedicato all'accoglienza dei visitatori.

I lavori durarono per quattro campagne $(1997-2000)^{3}$, finché lo scoppio della Seconda Intifada nel settembre del 2000 non costrinse la missione, che in quei giorni era operativa sul campo, a sospendere le attività. Negli anni successivi, furono ugualmente portate avanti le iniziative di ricerca (con diverse pubblicazioni), ma fino al 2005 non fu possibile tornare in Palestina. Nella primavera del 2005, in un nuovo quadro politico, d'accordo con il MOTA e la Cooperazione Italiana (con la collaborazione di Padre Michele Piccirillo o.f.m.), la Missione organizzò un convegno finalizzato al ripristino del sito archeologico e alla valorizzazione della miriade di altri monumenti presenti nell'Oasi ${ }^{4}$. Seguì nel 2008 un nuovo incontro con tutti i portatori di interesse locali, che servì da base per la ripresa delle investigazioni archeologiche e degli interventi di restauro a Tell es-Sultan nel $2009^{5}$ (fig. 2). Da allora sono state condotte altre nove campagne di scavo (2009-2017), che si sono concentrate sui monumenti delle Aree A, E (fig. 3) e T (pendici meridionali del tell), dell'Area B e B Ovest (fortificazioni del III millennio a.C.), dell'Area G (fig. 4-5; Palazzo del Bronzo Antico e del Bronzo Medio sulla Spring Hill), dell'Area F (fig. 6; quartiere abitativo settentrionale) e in altri numerosi cantieri minori. I risultati delle ricerche sono stati pubblicati in una serie di monografie ${ }^{6}$ e articoli ${ }^{7}$, edite dalla Missione. I frutti della

Matthiae 1997.

Nigro 2016

Marchetti - Nigro eds. 1998; 2000; Nigro 1999a; 1999b; Nigro - Marchetti 1998; 1999a; 1999b; 1999c; Nigro

- Marchetti - Sarie 1997; Nigro - Marchetti - Taha 2000; Nigro - Marchetti - Yassine 1999; Nigro et al. 2000.

Nigro 2006; Nigro - Taha eds. 2006.

Nigro - Taha 2009.

Nigro ed. 2000; 2010; Nigro et al. eds. 2011. 
costante attività di ricerca sono stati conseguiti grazie all'appoggio continuo della DGPSP Ufficio VI - Archeologia del Ministero degli Affari Esteri e della Cooperazione Internazionale.

Dal 2015, inoltre, in collaborazione con la Direzione Generale della Cooperazione allo Sviluppo, è stato avviato il Progetto "Oasi di Gerico" per la creazione del Parco Archeologico dell'Oasi di Gerico (JOAP - www.lasapienzatojericho/JOAP) e la formazione del personale che si occupa della valorizzazione turistica del Parco. Sono stati riabilitati e resi fruibili 16 siti maggiori presenti nell’Oasi, collegati da percorsi tematici naturalistici, religiosi e storico-culturali. Il centro del Parco è presso Tell es-Sultan, mentre le informazioni e le guide sono offerte ai visitatori dall'Info Point della Municipalità di Gerico $^{8}$ (figg. 7-8). Il progetto è stato avviato con successo e ha visto la partecipazione di numerosi giovani palestinesi, che conseguiranno una licenza di guide del Parco.

Gli stage di formazione realizzati nel corso del Progetto JOAP - Jericho Oasis Archaeological Park - hanno interessato molti giovani studenti palestinesi, che sono stati formati come archeologi, restauratori, ma anche guide turistiche e scolastiche a vantaggio dell'economia di Gerico e dello sviluppo sostenibile dell'Oasi.

Alla luce delle fruttuose esperienze maturate in più di quindici anni di attività congiunta nel campo della tutela e della ricerca archeologica e valorizzazione turistica, nel $2105^{9}$ il MOTA-DACH da un lato ha nuovamente scelto la Sapienza come partner per lo scavo di salvataggio della necropoli di Betlemme presso Khalet Jam' ${ }^{10}$ (figg. 9-10), dall'altro ha avviato un nuovo progetto di ricerca pluriennale, siglando un "Agreement on Cooperation", per lo scavo, lo studio e la valorizzazione del sito di Tell Sheikh Abu Zarad ${ }^{11}$ (figg. 11-12), un'antica città cananea e israelita che si trova al centro della Palestina, nella regione di Salfit, circa $15 \mathrm{Km}$ a sud di Nablus. Nei mesi di maggio giugno sono, dunque, state condotte congiuntamente con il MOTA-DACH la campagna di scavo di salvataggio e di documentazione dei materiali della necropoli di Khalet Jam'a e la prima campagna di prospezioni, survey e studio territoriale del sito di Tell Abu Zarad, identificato con la biblica Tappuah (citata in Luciano con il nome greco di Tefo). I risultati preliminari, pubblicati nello stesso anno, aprono un nuovo capitolo nello studio della Palestina antica, aggiungendo una città sinora assente dal quadro storico complessivo.

Nell'autunno successivo (2016), nuovamente, siamo stati chiamati a collaborare con l'Autorità palestinese in un intervento di salvage archaeology sempre a Betlemme ${ }^{12}$, nella necropoli di Jebel Daher ${ }^{13}$ (figg. 13-14). Lo scavo di una serie di tombe risalenti ad un arco cronologico compreso tra il Bronzo Antico IV e il Ferro II (2300-600 a.C.), come quello precedente a Khalet al-Jama, è stato prontamente pubblicato - sempre congiuntamente con il MOTA-DACH. Questo modus operandi, la speditezza nel produrre i risultati, l'attenzione alla preservazione dei luoghi oltre che dei reperti, alla classificazione corretta e, specialmente, alla conservazione di questi ultimi, hanno caratterizzato la nostra azione e

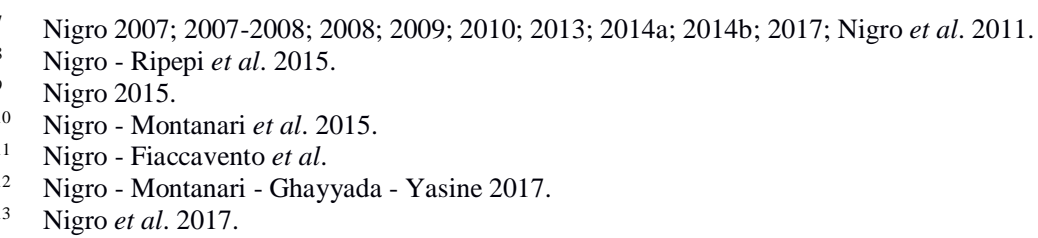


sono un valore riconosciuto e rispettato. Ma soprattutto, il lavoro sempre sinergico con il MOTA-DACH, l'attenzione prestata alla collaborazione e l'impostazione totalmente nuova del rapporto scientifico e di valorizzazione sono considerati un esempio nel Vicino Oriente.

\section{BIBLIOGRAFIA}

MARChetTi, N. - NigRO, L. (eds.)

1998 Scavi a Gerico, 1997. Relazione preliminare sulla prima campagna di scavi e prospezioni archeologiche a Tell es-Sultan, Palestina (Quaderni di Gerico 1), Roma 1998.

2000 Excavations at Jericho, 1998. Preliminary Report on the Second Season of Excavations and Surveys at Tell es-Sultan, Palestine (Quaderni di Gerico 2), Rome 2000.

Matthiae, $\mathrm{P}$.

1997 Ricerche archeologiche a Tell es-Sultan/Gerico: AA.Vv., Missioni archeologiche italiane. La Ricerca Archeologica Antropologica Etnologica (Ministero degli Affari Esteri. Direzione generale delle relazioni Culturali), Roma 1997, pp. 253-256.

NigRO, L.

1999a Sorprese dall’ultima campagna a Gerico: Archeologia Viva 74 (marzo/aprile 1999), pp. 36-47.

1999b Gerico - Jericho, numero monografico allegato alla rivista Realtà MAPEI, Milano 1999.

2006 Results of the Italian-Palestinian Expedition to Tell es-Sultan: at the Dawn of Urbanization in Palestine, in L. NIGRO - H. TAHA (eds.), Tell es-Sultan/Jericho in the Context of the Jordan Valley: Site Management, Conservation and Sustainable Development. Proceedings of the International Workshop Held in Ariha 7th - 11th February 2005 by the Palestinian Department of Antiquities and Cultural Heritage Ministry of Tourism and Antiquities, UNESCO Office - Ramallah, Rome "La Sapienza" University (Rome «La Sapienza» Studies on the Archaeology of Palestine \& Transjordan 2), Rome 2006, pp. 1-40.

2007 Aside the spring: Byblos and Jericho from village to town in the second half of the 4th millennium BC, in L. NigRo (ed.), Byblos and Jericho in the Early Bronze I: social dynamics and cultural interactions. Proceedings of the International Workshop held in Rome on March 6 $6^{\text {th }}$ 2007. by Rome "La Sapienza" University (Rome «La Sapienza» Studies on the Archaeology of Palestine \& Transjordan 4), Rome 2007, pp. 1-45.

2007-2008 Le tombe costruite sulla "Spring Hill” e i Signori di Gerico nel II millennio a.C., in G. BARTOLONi - G. BENEDETTINI (edd.), Sepolti tra i vivi. Evidenza ed interpretazione di contesti funerari in abitato. Atti del Convegno Internazionale di Studi, Università degli Studi di Roma “La Sapienza”, 26-29 Aprile 2006 (Scienze dell’Antichità 14/1), Roma 2007-2008, pp. 277-307.

2008 Tell es-Sultan/Jericho from Village to Town: A Reassessment of the Early Bronze Age I Settlement and Necropolis, in J.Ma . CóRDOBA - M. Molist - Ma.C. PÉREZ - I. RUBiO - S. Martínez (eds.), Proceedings of the 5th International Congress on the Archaeology of the Ancient Near East (5-8 April 2006), Madrid 2008, Volume II, pp. 645-662.

2009 When the Walls Tumble Down. Jericho: Rise \& Collapse of an Early Bronze Age Palestinian City, in A. CARDARELli (ed.), Le ragioni del cambiamento. Reasons for Change. 'Nascita', 'declino' $e$ 'crollo' delle società tra fine del IV e inizio del I millennio a.C. (Scienze dell'Antichità 15), Roma 2009, pp. 173-192.

2010a Tell es-Sultan/Jericho and the Origins of Urbanization in the Lower Jordan Valley: Results of Recent Archaeological Researches, in P. MATTHAIE - F. PINNOCK - L. NigRO - 
N. MARChetTi (eds.), 6 ICAANE. Proceedings of the $6^{\text {th }}$ International Congress of the Archaeology of the Ancient Near East. 5 May - 10 May 2008, "Sapienza”, Università di Roma, Wiesbaden 2010, Volume 2, pp. 459-481.

2013 Jericho: D.M. MASTER (ed.), The Oxford Encyclopedia of the Bible and Archaeology, vol. II, Oxford 2013, pp. 1-8.

2014a Aside the Spring: Tell es-Sultan/Ancient Jericho: the Tale of an Early City and Water Control in Ancient Palestine, in T. TVEDT - T. OestigaArd (eds.), A History of Water. Series III. Volume 1: Water and Urbanization, London 2014, pp. 25-51.

2014b The Archaeology of Collapse and Resilience: Tell es-Sultan/ancient Jericho as a Case Study, in L. Nigro (ed.), Overcoming Catastrophes. Essays on disastrous agents characterization and resilience strategies in pre-classical Southern Levant (Rome «La Sapienza» Studies on The Archaeology of Palestine \& Transjordan 11), Rome 2014, pp. 55-85.

2015 Bethlehem in the Bronze and Iron Age. A Summary in the light of recent discoveries by The Palestinian MOTA-DACH: Vicino Oriente XIX (2015), pp. 1-15.

2016 Tell es-Sultan 2015. A Pilot Project for Archaeology in Palestine: Near Eastern Archaeology 79:1 (2016), pp. 4-17.

NigRo, L. (ed.)

2000 Tell es-Sultan/Gerico alle soglie della prima urbanizzazione: il villaggio e la necropoli del Bronzo Antico I (3300-3000 a.C.) (Rome «La Sapienza» Studies on the Archaeology of Palestine \& Transjordan 1), Roma 2005.

2010 Tell es-Sultan/Jericho in the Early Bronze II (3000-2700 BC): the rise of an early Palestinian city. A synthesis of the results of four archaeological expeditions (Rome «La Sapienza» Studies on the Archaeology of Palestine \& Transjordan 5), Rome 2010.

2017 The end of the Early Bronze Age in the Southern Levant. Urban Crisis and Collapse seen from two $3^{\text {rd }}$ Millennium BC-Cities: Tell es-Sultan/Jericho and Khirbet al-Batrawy, in T. Cunninghm - J. Driessen (eds.), Crisis to Collapse. The Archaeology of Social Breakdown (AEGIS 11), Louvain 2017, pp. 149-172.

Nigro, L. - FiaccaVento, C. - JaRAdAt, M. - Yasine, J.

2015 Archaeology from A to Z: Abu Zarad, an Ancient Town of Palestine: Vicino Oriente XIX (2015), pp. 139-183.

NigRo, L. - MARCHETTI, N.

1998 Preliminary Report on the First Season of Excavations of the Italian-Palestinian Expedition at Tell es-Sultan/Jericho, April-May 1997: Palestine Exploration Quarterly 130 (1998), pp. 121-144.

1999a Two Seasons of Excavations of the Italian-Palestinian Expedition at Tell esSultan/Jericho, in AA.VV. Culture in Sustainable Development. An Italian Strategy. Research and Pilot Projectson Archaeology and Anthropology, Rome 1999, pp. 103-107.

1999b A la derécouverte de Jéricho: Les Dossier d’Archéologie 240 (Jan./Fev. 1999), pp. 91-97.

1999c La porta di Gerico: Archeo 167 (gennaio 1999), pp. 10-12.

NigRo, L. - MARChETTI, N. - SARIE, I.

1997 First Season of Excavations of the Italian-Palestinian Expedition at Tell es-Sultan/Jericho, April-May 1997: Orient Express 1997/2, pp. 1-4.

NigRo, L. - MARCHETTI, N. - TAHA, H.

2000 Preliminary Report on the Second Season of Excavations of the Italian-Palestinian Expedition at Tell es-Sultan/Jericho, 199, in P. Matthiae - A. EnEA - L. PeYronel - F. PINNOCK (eds.), Proceedings of the First International Congress on the Archaeology of the Ancient Near East, Rome, May $18^{\text {th }}-23^{\text {rd }} 1998$, Rome 2000, pp. 869-901. 
NigRo, L. - MARChETTI, N. - YASSine, J.

1999 Second Season of Excavations of the Italian-Palestinian Expedition at Tell esSultan/Jericho, October-November 1998: Orient Express 1999/1, pp. 17-20.

Nigro, L. - MARChetTi, N. - YAsSine, J. - GHAYADA, M.

2000 Third Season of Excavations of the Italian-Palestinian Expedition at Tell esSultan/Jericho, October-November 1999: Orient Express 2000/4, pp. 82-84.

Nigro, L.- Montanari, D. - GhayyadA, M. - YAsine, J.

2015 Khalet al-Jam'a. A Middle Bronze and Iron Age necropolis near Bethlehem (Palestine): Vicino Oriente XIX (2015), pp. 185-218.

2017 The el-Atan Tomb: an Early Bronze IVB female burial in the heart of Bethlehem: Vicino Oriente XXI (2017), pp. 225-256.

Nigro, L. - Montanari, D. - Guari, A. - TAmburRini, M. - Izzo, P. - GhayyadA, M. - Titi, I. YASINE, J.

2017 New archaeological features in Bethlehem (Palestine): the Italian-Palestinian rescue season of 2016: Vicino Oriente XIX (2017), pp. 5-57.

NigRO, L. - RIPEPI, G. - HAMDAN, I. - YASINE, J.

2015 The Jericho Oasis Archaeological Park - 2015 Interim Report. Italian-Palestinian Cooperation for protection and valorization of archaeological heritage: Vicino Oriente XIX (2015), pp. 219-247.

Nigro, L. - SALA, M. - TAHA, H. (eds.)

2011 Archaeological Heritage in the Jericho Oasis. A systematic catalogue of archaeological sites for the sake of their protection and cultural valorization (Rome «La Sapienza» Studies on the Archaeology of Palestine \& Transjordan 7), Rome2011.

NigRo, L. - SALA, M. - TAHA, H. - YASSine, J.

2011 The Early Bronze Age Palace and Fortifications at Tell es-Sultan/Jericho. The $6^{\text {th }}-7^{\text {th }}$ seasons (2010-2011) by Rome "La Sapienza" University and the Palestinian MOTADACH: Scienze dell’Antichità 17 (2011), pp. 571-597.

NigRO, L. - TAHA, H.

2009 Renewed Excavations and Restorations at Tell es-Sultan/Ancient Jericho. Fifth Season March-April 2009: Scienze dell'Antichità 15 (2009), pp. 733-744.

Nigro, L. - TAHA, H. (eds.)

2006 Tell es-Sultan/Jericho in the Context of the Jordan Valley: Site Management, Conservation and Sustainable Development. Proceedings of the International Workshop Held in Ariha $7^{\text {th }}-11^{\text {th }}$ February 2005 by the Palestinian Department of Antiquities and Cultural Heritage - Ministry of Tourism and Antiquities, UNESCO Office - Ramallah, Rome "La Sapienza" University (Rome «La Sapienza» Studies on the Archaeology of Palestine \& Transjordan 2), Rome 2006. 
Fig. 1 - Pianta generale del sito di Tell es-Sultan, antica Gerico.
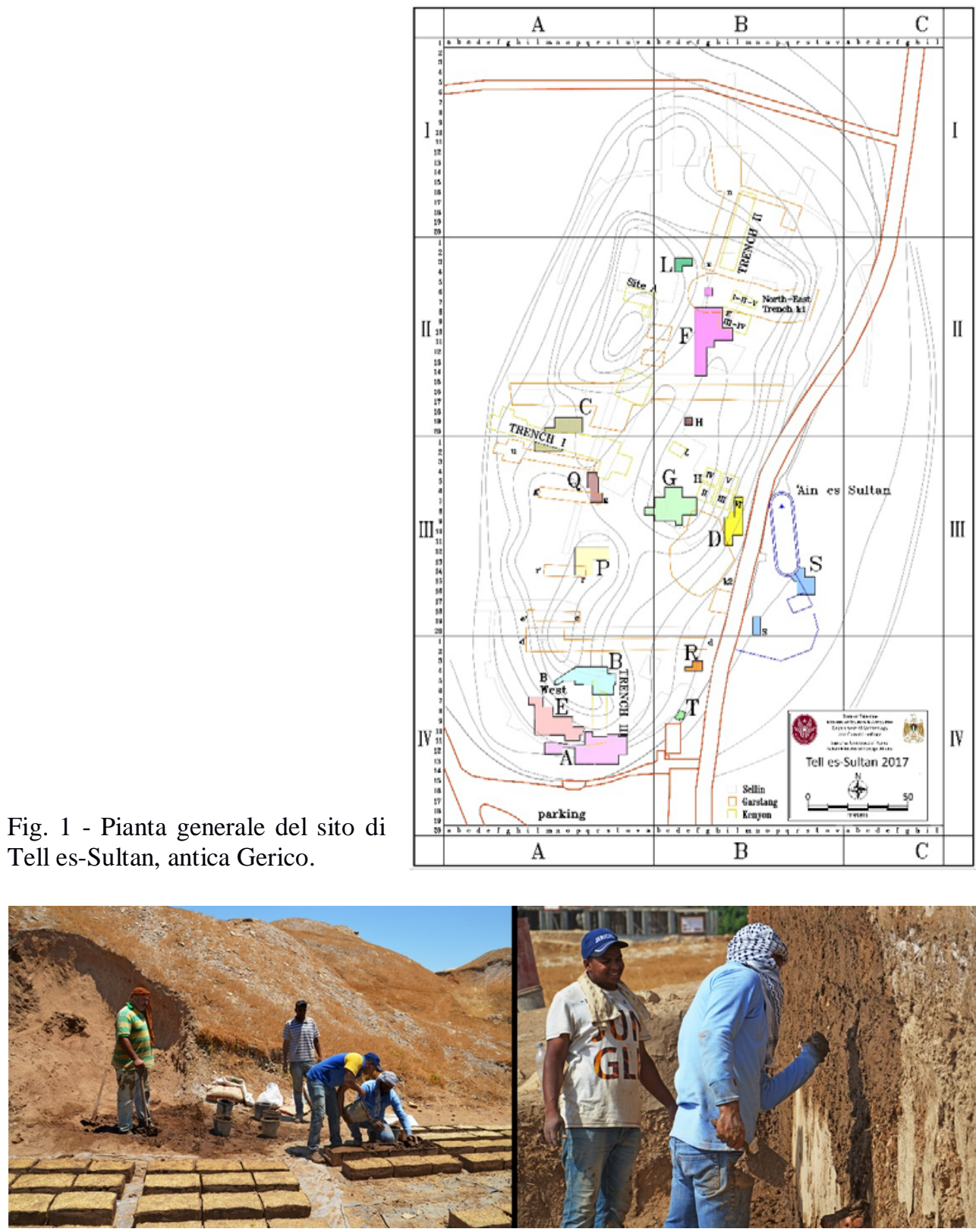

Fig. 2 - Alcuni momenti delle attività di restauro sul sito di Tell es-Sultan: la realizzazione dei mattoni crudi secondo le tecniche tradizionali (sinistra) e la messa in opera dei mattoni (destra). 


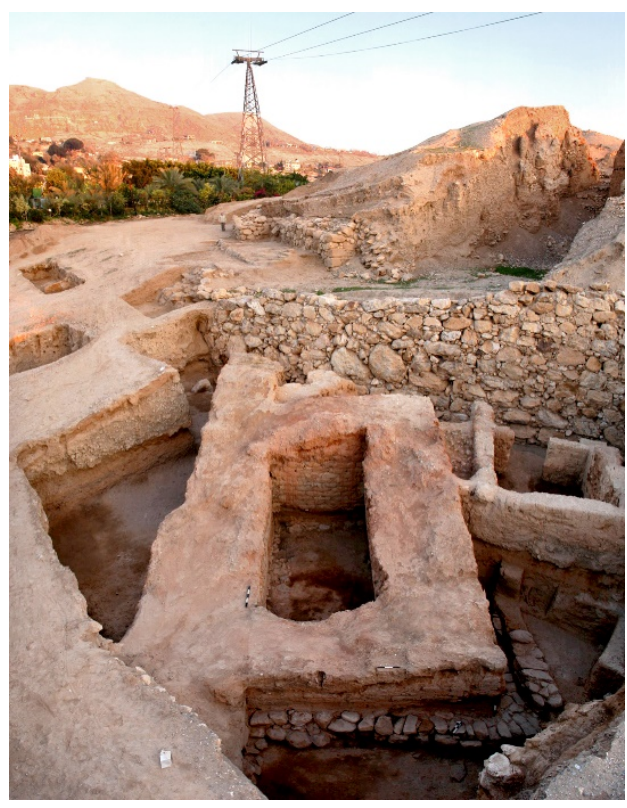

Fig. 3 - Veduta generale dell'Area A, in primo piano, e dell'Area E, sullo sfondo, con la Torra A1 del Bronzo Medio I-II (19001650 a.C.); da sud-est.

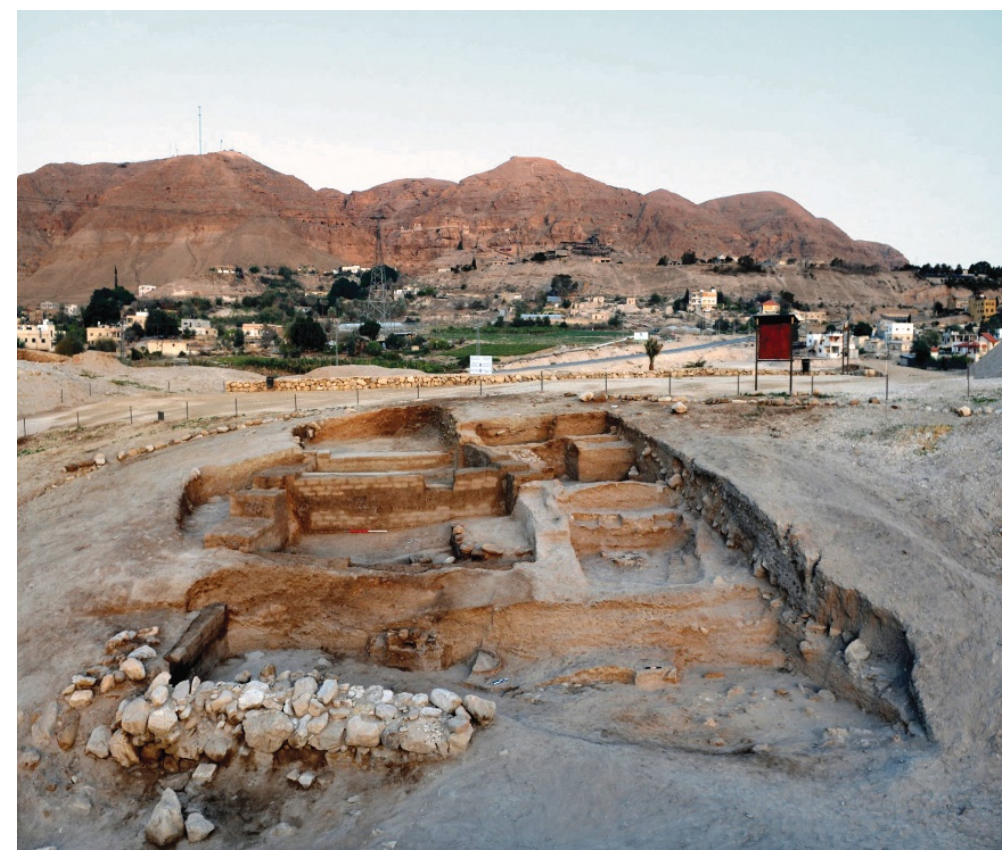

Fig. 4 - Veduta generale del Palazzo G del Bronzo Medio IIIB (2450-2300 a.C.); da est. 

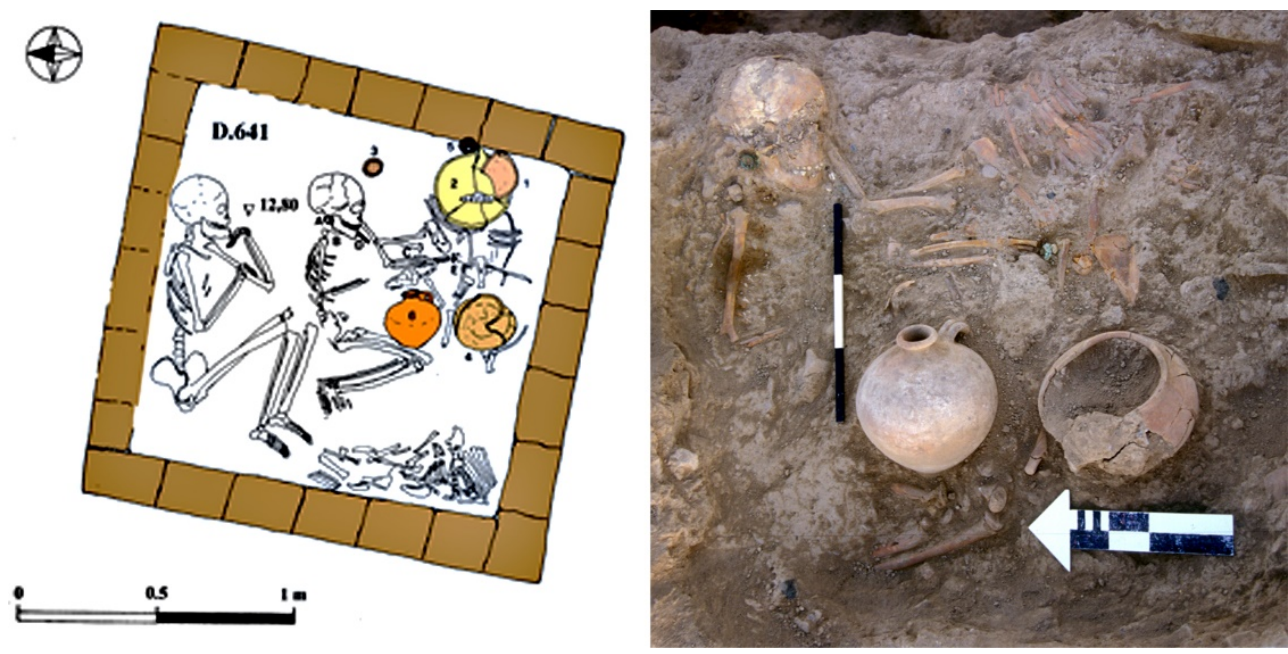

Fig. 5 - Pianta e foto al momento della scoperta della Tomba D.641 (1850-1800 a.C.) sulla Spring Hill di Tell es-Sultan/antica Gerico.

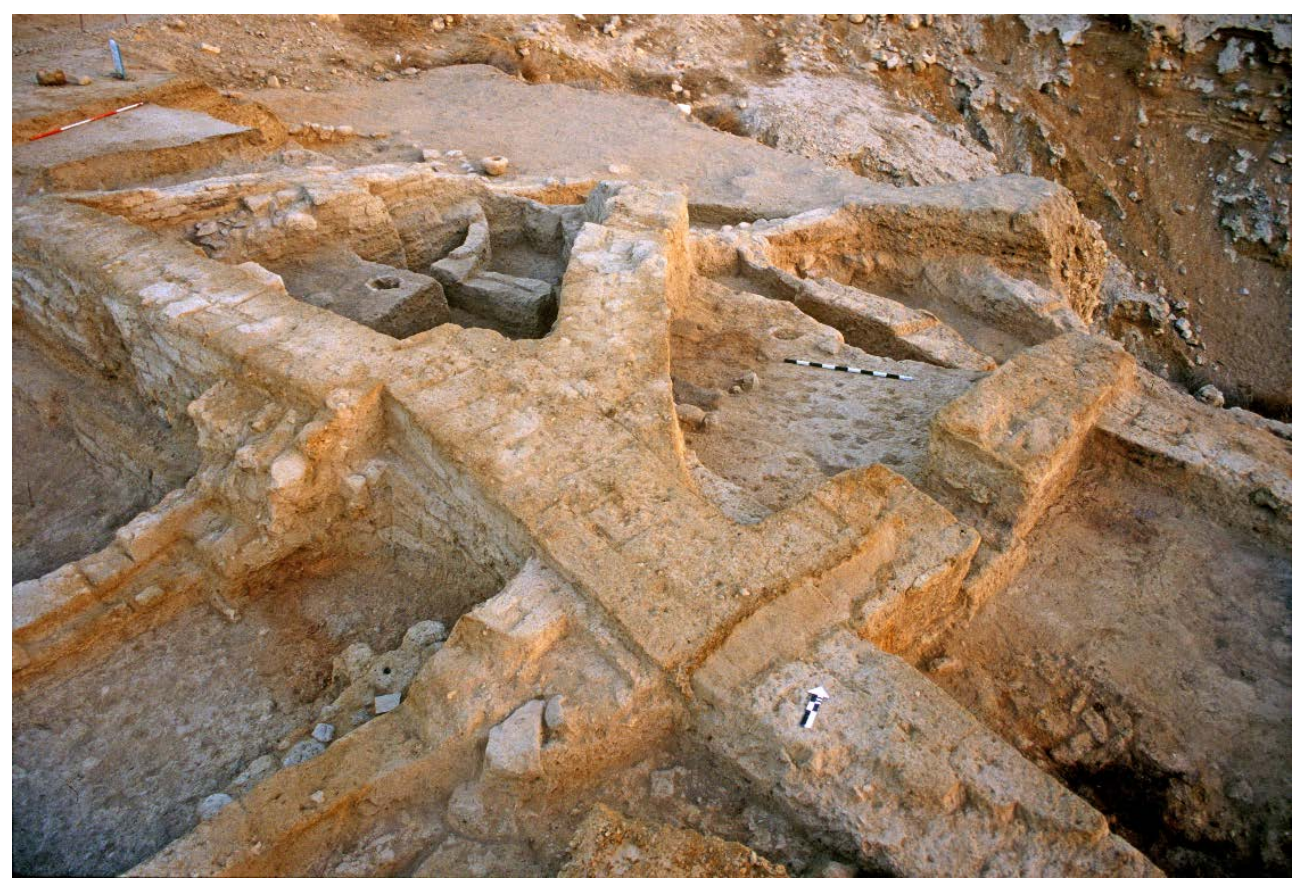

Fig. 6 - Veduta generale del quartiere domestico dell'Area F del Bronzo Antico IIIA (26502350 a.C.). 


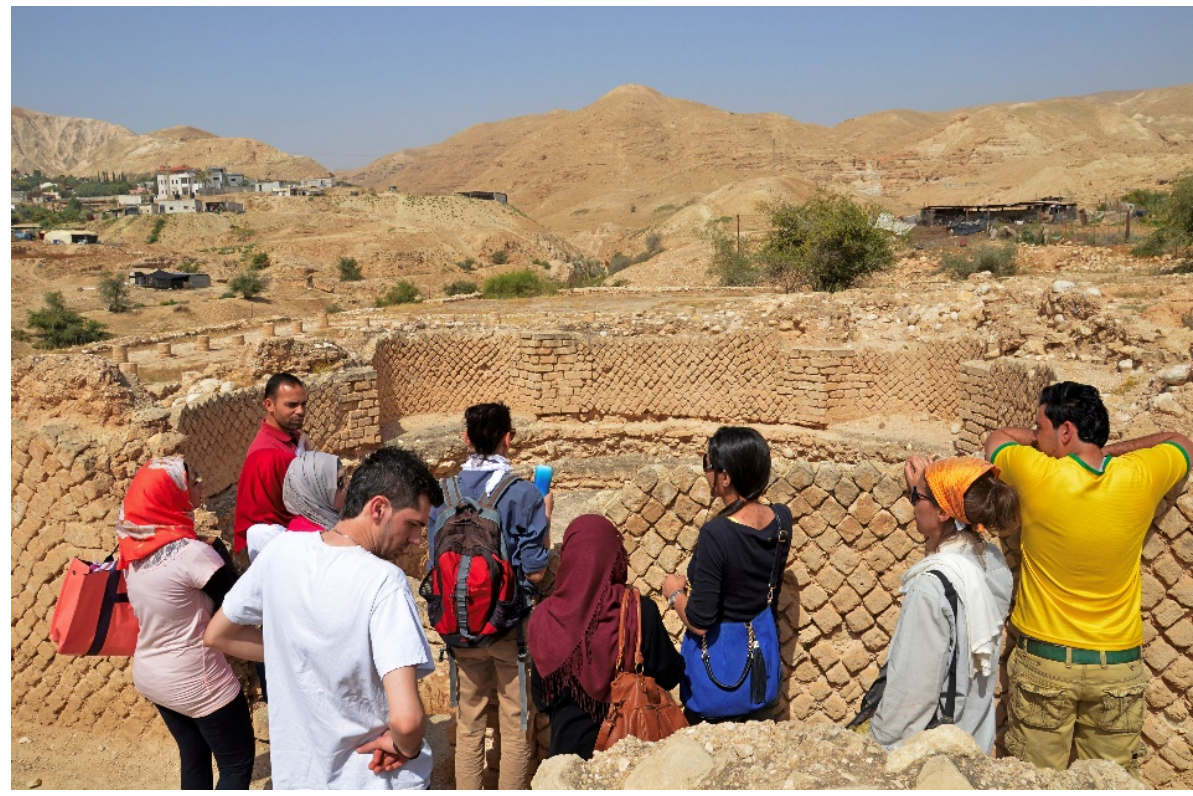

Fig. 7 - Gli studenti del JOAP in visita al sito di Tulul Abu el-'Alayiq.

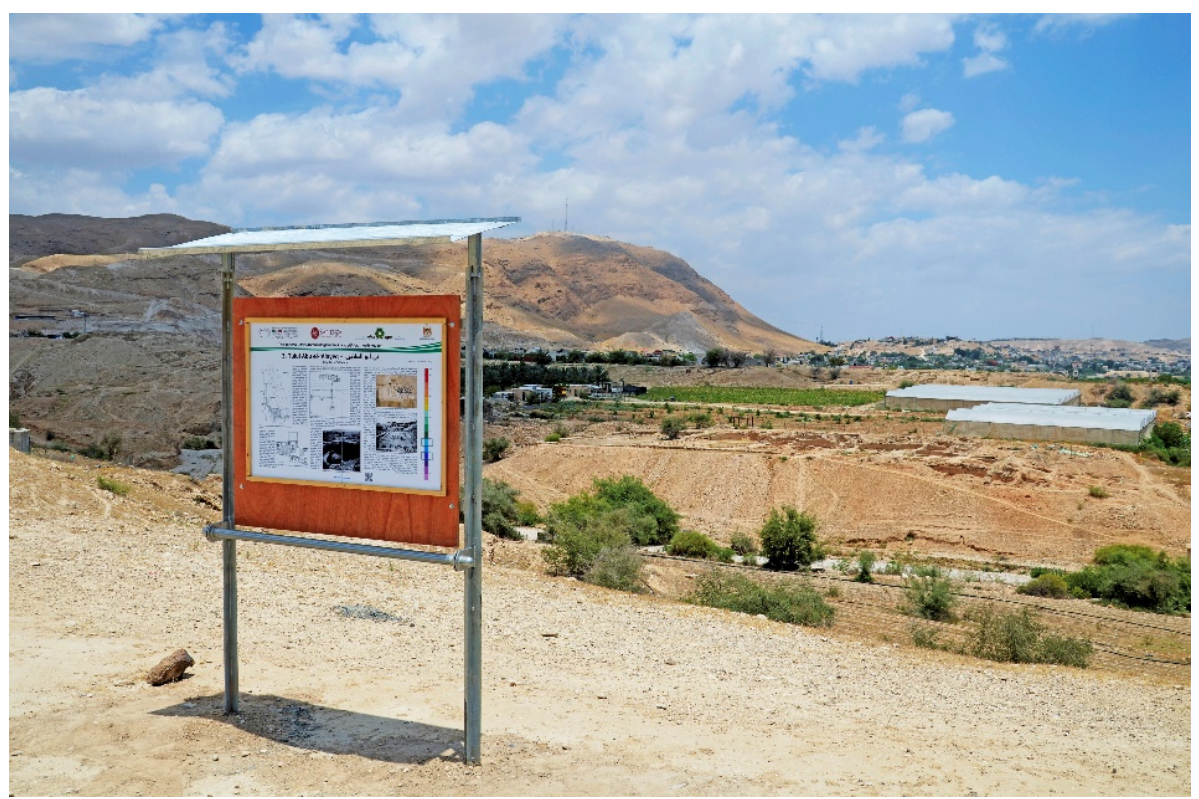

Fig. 8 - Il pannello informative del sito di Tulul Abu el-‘Alayiq. 


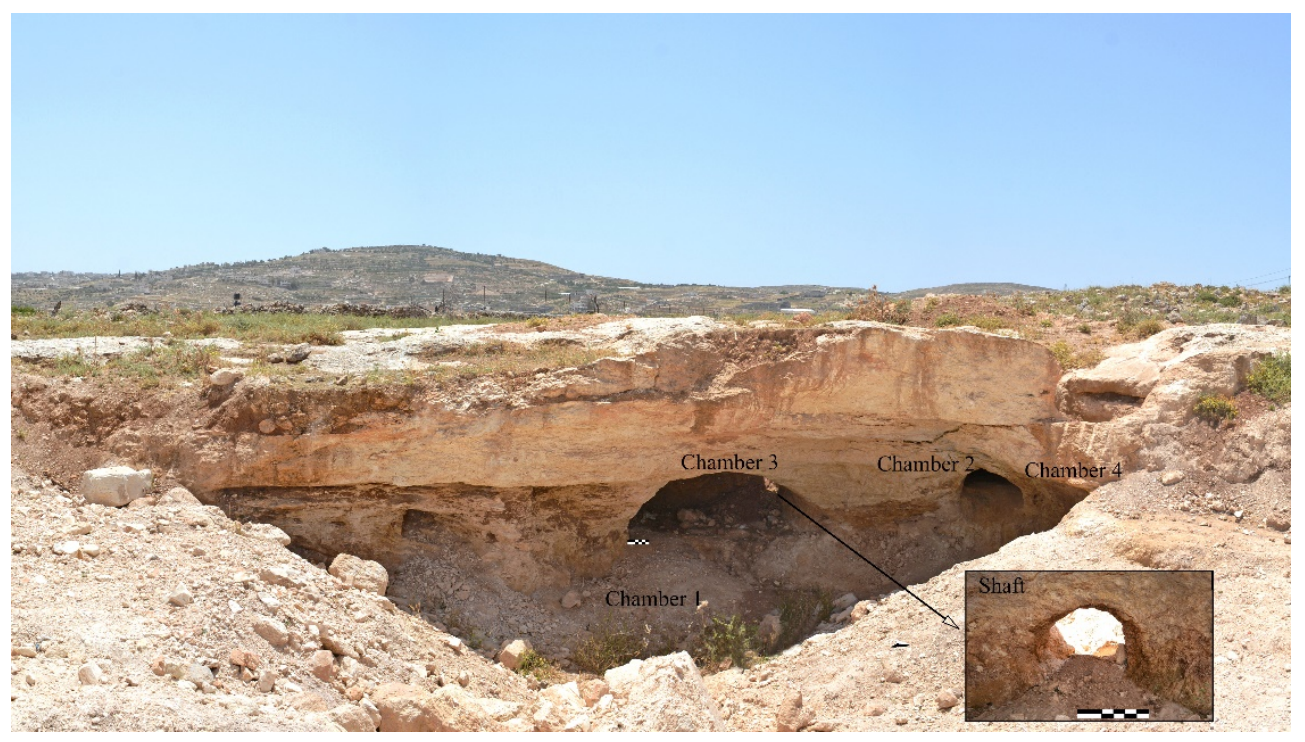

Fig. 9 - La necropoli di Khalet al-Jam'a con in primo piano la Tomba A1 danneggiata dalle attività edilizie; da nord-est.
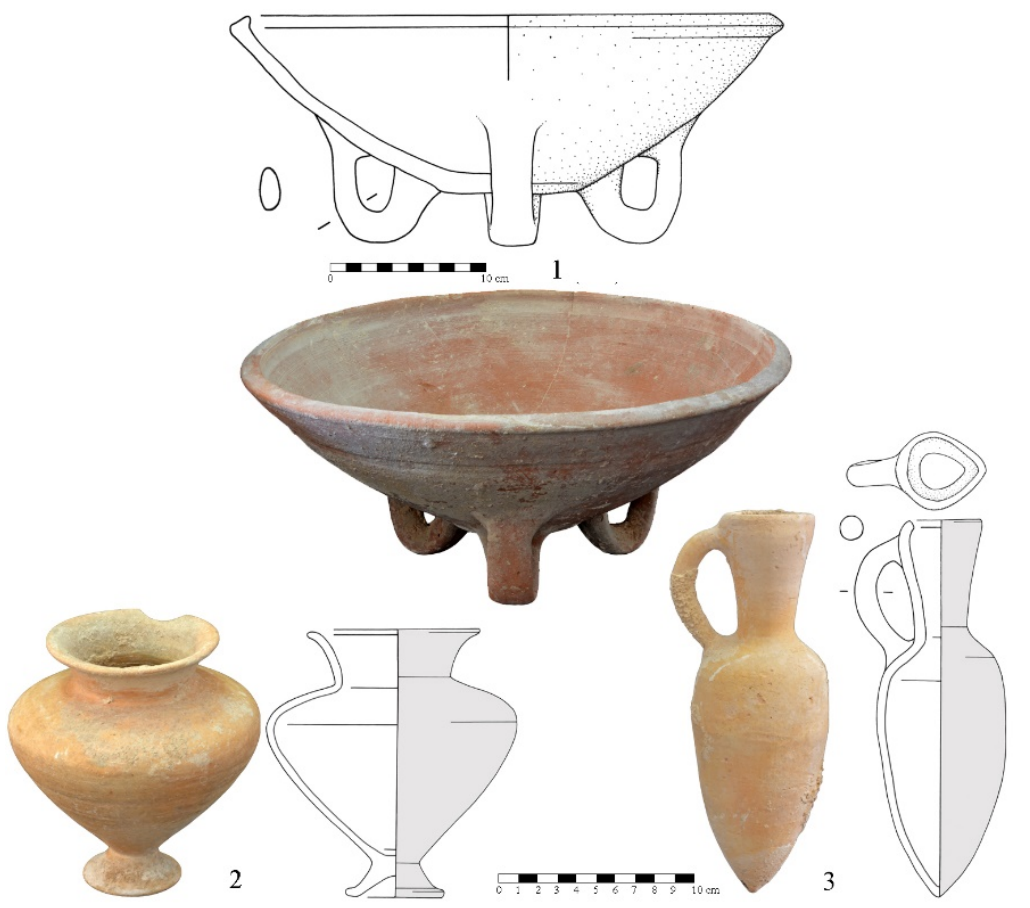

Fig. 10 - Alcuni reperti del Bronzo Medio della Tomba A2 della necropoli di Khalet alJam'a. 


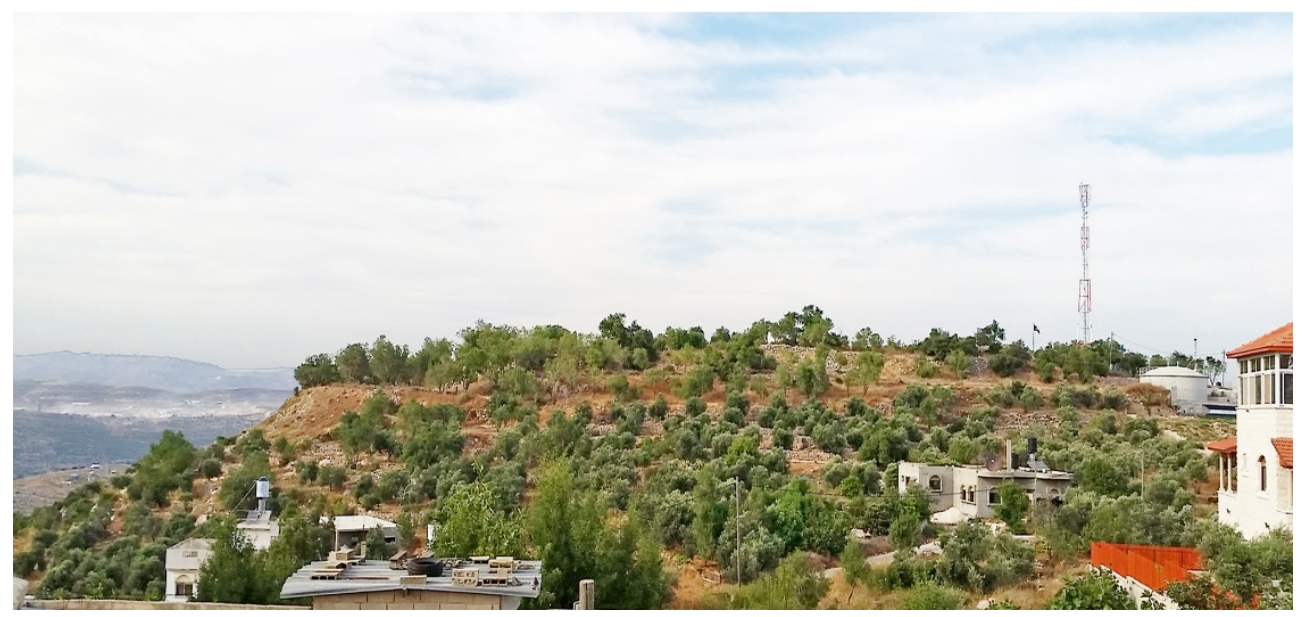

Fig. 11 - Veduta generale del sito di Tell Sheikh Abu Zarad nella regione di Salfeet; da ovest.
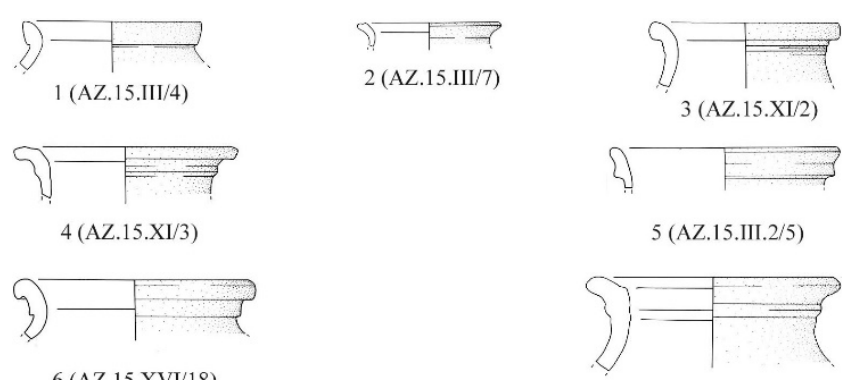

$6(\mathrm{AZ} .15 . \mathrm{XVI} / 18)$
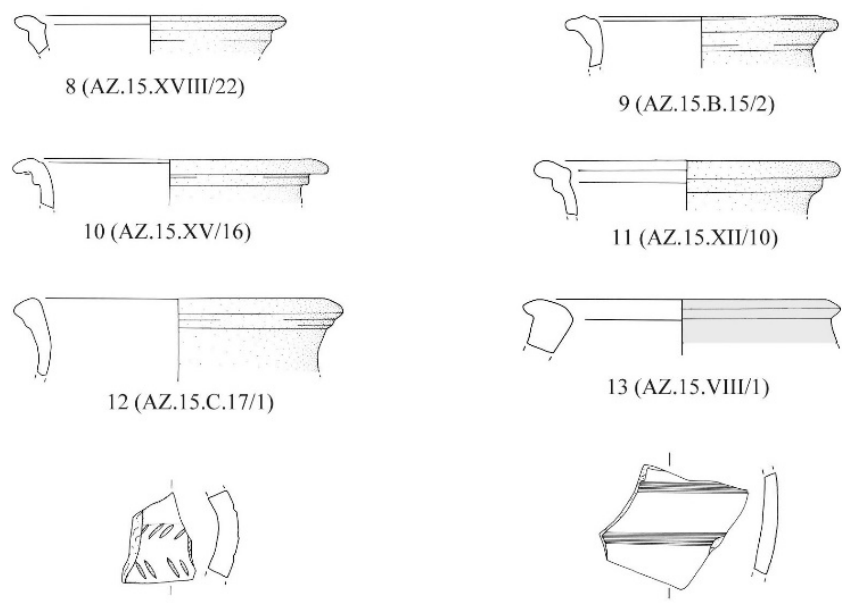

$14(\mathrm{AZ} .15 \cdot \mathrm{XI} / 10)$

Fig. 12 - Alcuni reperti ceramici del Brono Medio IIIII (1800-1550 a.C.) da Tell Sheikh Abu Zarad. 
Fig. 13 - Pianta della necropoli di Jebel Dhaher scoperta nell'autunno del 2016.
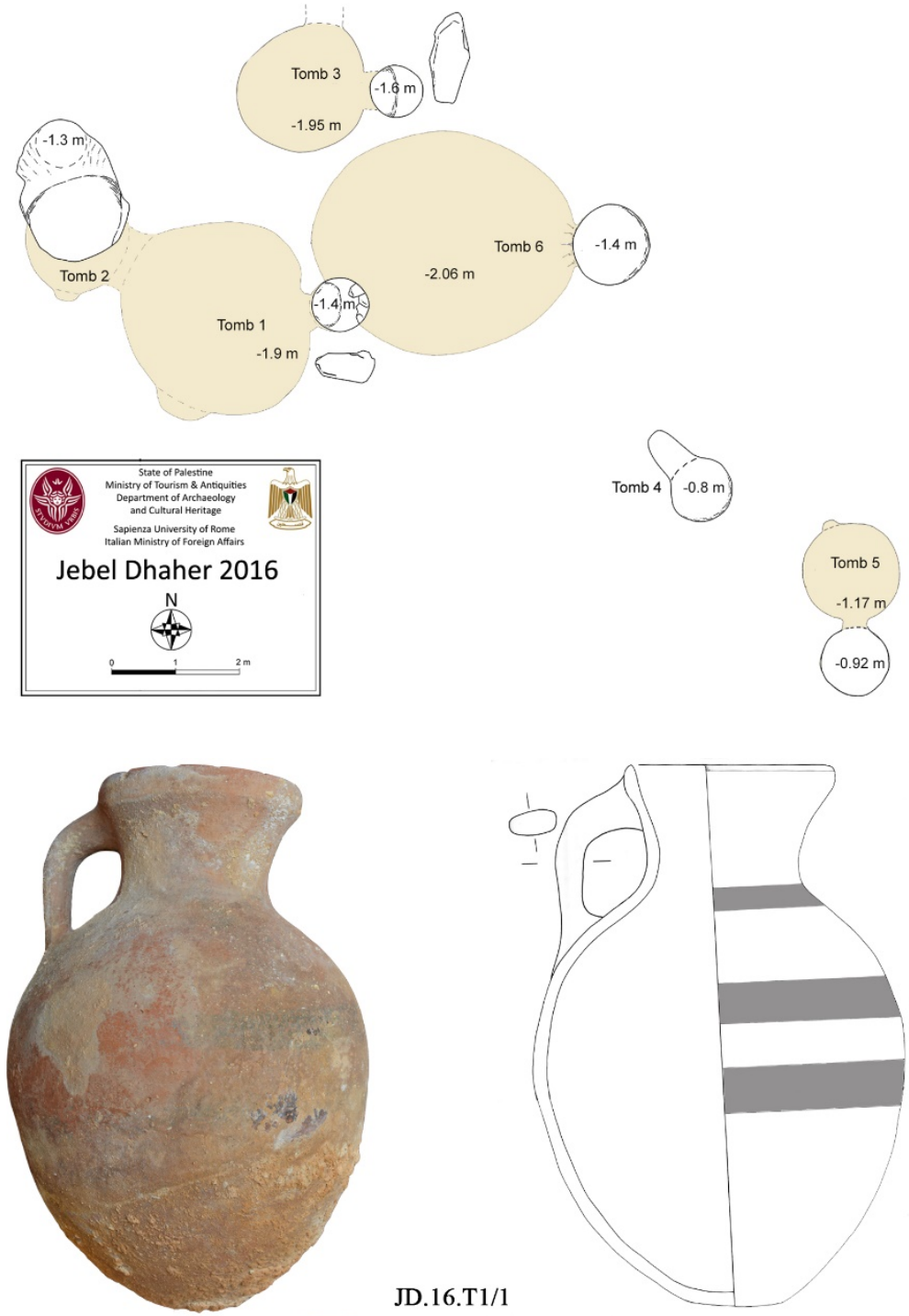

Fig. 14 - Ceramica del Bronzo Medio dalla Tomba 1 di Jebel Dhaher.

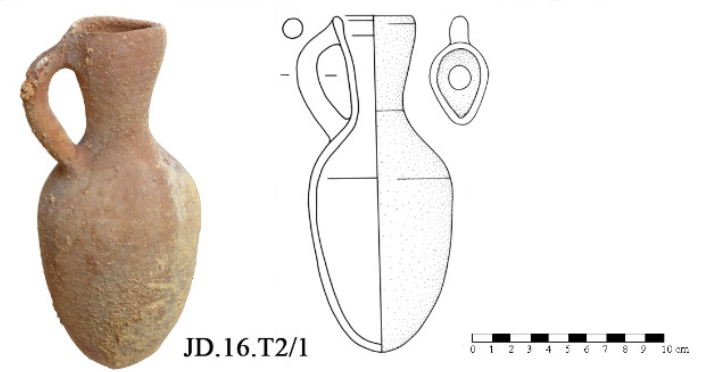

